\title{
Article \\ High Dimension Granite Pavement Bio-Desalination Practical Implementation
}

\author{
Pilar Bosch-Roig ${ }^{1, *(\mathbb{C}}$, Lourdes Pérez-Castro ${ }^{2}$, Ángeles Fernández-Santiago ${ }^{3}$ and Ignacio Bosch ${ }^{4}[$ \\ 1 Instituto de Restauración del Patrimonio, Universitat Politècnica de València, 46022 Valencia, Spain \\ 2 Consorcio de la Ciudad de Santiago, Rúa do Vilar, 59, 15702 Santiago de Compostela, Spain; \\ lourdespc@consorciodesantiago.org \\ 3 Alfa ArteRestauración S.L., Sobrada, Torrón 23, 36739 Tomiño, Spain; anxos.santiago@gmail.com \\ 4 Instituto de Tecnologías y Aplicaciones Multimedia, Universitat Politècnica de València, \\ 46022 Valencia, Spain; igbosroi@dcom.upv.es \\ * Correspondence: mabosroi@upvnet.upv.es
}

Citation: Bosch-Roig, P.; PérezCastro, L.; Fernández-Santiago, Á.; Bosch, I. High Dimension Granite Pavement Bio-Desalination Practical Implementation. Appl. Sci. 2021, 11, 6458. https://doi.org/10.3390/ app11146458

Academic Editors: Filomena De Leo and Valme Jurado

Received: 27 May 2021

Accepted: 11 July 2021

Published: 13 July 2021

Publisher's Note: MDPI stays neutral with regard to jurisdictional claims in published maps and institutional affiliations.

Copyright: (c) 2021 by the authors. Licensee MDPI, Basel, Switzerland. This article is an open access article distributed under the terms and conditions of the Creative Commons Attribution (CC BY) license (https:/ / creativecommons.org/licenses/by/ $4.0 /)$.
Featured Application: This work has developed an innovative and optimized in situ high dimension bio-desalination application protocol that has been applied for the bio-desalination of the $233 \mathrm{~m}^{2}$ Conxo Chapel granite pavement. This optimized protocol has the potential to be transferable to other large scale in situ biocleaning strategies.

Abstract: Biocleaning technology is based on the use of safe environmental microorganisms for green cultural heritage $(\mathrm{CH})$ restoration. Compared with traditional cleaning products, this biological technique is very specific, effective, and nontoxic. This innovative biotechnological application has been used for recovering diverse monuments and artworks. Most $\mathrm{CH}$ in situ surfaces that are treated with microorganisms are small areas; however, some important pathologies, such as salt contamination, can affect high dimension artistic surfaces. The purpose of this study is to analyze and overcome the problems and limitations of scaling up the bio-desalination protocol for in situ applications. Three water-based gel delivery systems and three heating systems were tested in situ and evaluated in terms of performance difficulty, efficacy, and costs. The tests were carried out on the salt contaminated granite pavement of Cristo Chapel of Sta Ma de Conxo in Santiago de Compostela (Spain). Ground agar $\%$ and a heating electric mat were selected as the best performing systems. The implemented protocol was applied for the bio-desalination of the $233 \mathrm{~m}^{2}$ Chapel pavement. Conductivity, nitrate-nitrite measurements, biological monitoring, and digital image analysis were performed to determine the efficacy of the treatment. This research allowed for the development of an innovative and optimized in situ, high dimension bio-desalination application protocol transferable to other large scale, in situ biocleaning strategies.

Keywords: bio-desalination; biocleaning; nitrate; bacteria; cultural heritage; granite pavement

\section{Introduction}

Cultural heritage $(\mathrm{CH})$ is our past generation's legacy that must be conserved for future generations. Different circumstances, such as pollution, inadequate old restorations, salt contamination, and climate change are damaging these artworks and monuments. In order to properly conserve them, they need to be restored.

Among the many "diseases" present on CH monuments, alterations, such as black crust, salts, organic residues, and graffiti, are similar in that they are all difficult to clean with traditional methodologies. Therefore, there is a need to develop and standardize a more effective and safe technology. The majority of the current cleaning techniques are physical and/or chemical methods. These traditional techniques involve risks for the applicators, general public, artworks, and environment. These risks include health risks (linked, among other things, to the inhalation and touching of toxic cleaning chemicals), environmental 
contamination (most of the time, chemicals used for cleaning simply flow into the sewage system), and $\mathrm{CH}$ alteration (due to the lack of specificity of these traditional techniques).

Due to the risks associated with traditional $\mathrm{CH}$ cleaning techniques, an important demand for less risky cleaning products currently exists. The $\mathrm{CH}$ sector is asking for more "green" sustainable products as valid alternatives and even to substitute for the chemical methods. An existing demand for less time-consuming cleaning techniques also exists in order to augment the efficiency of the interventions and to reduce personnel costs.

In order to solve these problems, innovative, fast, and safe biological cleaning techniques have been developed in the last two decades. These alternative microbial biotechnologies use natural living organisms instead of toxic chemical substances [1] to avoid health and environmental problems [2]. In addition, these techniques are very specific, allowing proper preservation of the treated artwork while avoiding $\mathrm{CH}$ alterations due to the restoration process. They are also time-saving techniques that reduce personnel related costs. Therefore, biotechnology applied to $\mathrm{CH}$ restoration has become a successful, novel alternative to traditional conservation and preservation approaches [3].

This biorestoration technology, in the last two decades, has been effectively tested and validated experimentally at the lab scale and on in situ $\mathrm{CH}$ materials (such as artworks and monuments). Many authors have reported the use of different appropriately selected microorganisms for removing black crust (mostly sulfates), salts (bio-desalination), organic residues (mostly animal glue), and graffiti, among others, from organic and inorganic artistic materials. Most of the reported biocleaning methods are used as a cleaning alternative alone or in combination with other treatments when traditional techniques are ineffective, aggressive, or dangerous [4-6]. However, some authors show that they can be even the first option. Giuventù et al. (2011) carried out a comparative study showing the efficient removal of black crust on the colored lithotypes of Florence Cathedral by using Desulfovibrio vulgaris subsp. vulgaris compared with chemical and laser treatment [7]. Our previous studies have shown that a Pseudomonas stutzeri bio-desalination treatment was the most effective method compared to the most frequently used desalination methods [8].

The dimensions of $\mathrm{CH}$ artifacts can vary significantly, from a few millimeters (small artworks) to many square meters (large monuments). Also, $\mathrm{CH}$ pathologies can affect small or huge areas. One of the pathologies that affects larger surfaces is salt contamination of artistic stone, which frequently affects historical monuments. According to the literature, most of the $\mathrm{CH}$ in situ stone surfaces treated with microorganisms are small areas whose dimensions are usually not indicated (n.i.), and of those studies that do report the area, dimensions typically vary from $1 \mathrm{~cm}^{2}$ to $95 \mathrm{~m}^{2}$ [4]. Artistic treated items include sculptures such as: Pietà Rondanini by Michelangelo; the marble column and statue $(2.2 \mathrm{~m}$ high and $60 \mathrm{~cm}$ deep) of the writer Neera by Lina Arpesani in the Cemetery of Milan; the Demetra and Cronos limestone sculpture from the courtyard of the Buonconsiglio Castle in Trento created by Jacob Eberle (n.i.); the marble polychrome artifact in Galleria Regionale Sicilia in Palermo (n.i.) [4,9-12], mural paintings such as: the indoor vault fresco lunette $\left(25 \mathrm{~m}^{2}\right)$ in the Santos Juanes church in Valencia; three detached frescoes at Camposanto Monumentale in Pisa $\left(27 \mathrm{~m}^{2}, 84 \mathrm{~m}^{2}, 95 \mathrm{~m}^{2}\right.$, respectively); external vault tempera mural paintings in Chiesa S. Apollinare in Trento (n.i.); a mural painting in loggia di Cassina Farnese in Rome (n.i.); a mural painting in Queen Teodolinda Chapel in Monza Cathedral (n.i.); a mural painting in Cappella S. Pietro in Chiesa S. Prudenza in Rome (n.i.); a mural painting by Orazio Riminaldi in cupula del Duomo di Pisa (n.i.); an oil mural painting from Mussei Vaticani in Rome (n.i.) [13-21], and monuments such as: a $5 \mathrm{~m}^{2}$ area of the external sandstone walls at Matera Cathedral; three areas $\left(15 \times 15 \mathrm{~cm}^{2}\right)$ of external colored marble lithotypes at Florence Cathedral; a granite pavement slab $(60 \mathrm{~cm} \times 40 \mathrm{~cm} \times 15 \mathrm{~cm})$ at the Santa Maria del Conxo chapel in Santiago de Compostela [7,8,22,23]. The frescoes at Camposanto Monumentale of Pisa have been the highest dimension artworks treated with biocleaning technology. These three 14th Century detached frescoes have been completely biocleaned: "Conversione Saint Efisio e battaglia" by S. Aretino (3.5 $\mathrm{m} \times 7.8 \mathrm{~m})$; "Stories of the Holy Fathers" (6.10 m × $15.65 \mathrm{~m})$, and "Trionfo della Morte" by B. Buffalmarco 
(5.6 $\mathrm{m} \times 15.0 \mathrm{~m})$ using Pseudomonas stutzeri A29. The authors developed an optimized biocleaning protocol for ex situ fresco restoration based on cotton wool as the delivery system and a central heating system for temperature control because the restoration was carried out in a laboratory $[14,21,24]$. However, to the best of our knowledge, no high dimension biocleaning for real $\mathrm{CH}$ in situ applications has yet been reported.

The challenge of this research was to analyze and overcome the problems and limitations of scaling up the protocol for $\mathrm{CH}$ in situ application. Therefore, the objective was to implement an innovative and optimized in situ biocleaning protocol that is applicable to high dimension surfaces. Bacterial biomass production, temperature conditioning, delivery systems, performance difficulty, cleaning efficiency, and economic costs were all factors that were considered.

In particular, we focused on the bio-desalination of the high dimension granite pavement of the Cristo Chapel of Santa María de Conxo Monastery. The pavement is affected by high nitrate salt contamination that affects its visual appearance $[8,25]$. The relative humidity $(\mathrm{RH})$ inside the Chapel is high ( $75-80 \%$ mean values) because the city, proximal to the ocean, also has a high air humidity level most of the year ( $80 \%$ mean values). This high humidity alters the chapel pavement by darkening the granite slabs. In order to reduce water entering the Chapel, in 2013, the Santiago Consortium promoted work to prevent the free fall of rainwater on the walls (gutters and downspouts were placed). The exterior grouting of the chapel's walls was improved, gaps (through which the water entered) were eliminated, and perimeter drainage was executed in order to separate the construction from the cemetery and prevent the entry of water from there. In 2015, a hygrothermal study revealed that the ground was wet under the slabs, and that this moisture was abnormally retained, both in the ground and in the stone, due to the presence of hygroscopic salts [25]. Previous studies have analyzed the pavement using chemical analysis. Fourier Transform Infrared (FTIR) analysis showed that the chemical composition of the pavement was quartz, feldspar, calcite, and kaolinite group minerals correlating with granite stone. Photometric, semi-quantitative test strips and FTIR analyzes of soluble salt content found mostly nitrate $[8,25]$.

Salt contamination is higher on the surface of the slabs than on the lower part. This has a double effect: on the one hand, it retains the humidity that comes from the ground, but on the other, it attracts and condenses water vapor from the air. These two mechanisms prevent the drying of the pavement and, therefore, lead to the darkening of it [25]. To solve the problem of saline contamination, there was a need to proceed with pavement desalination.

On the basis of previous works, we selected Pseudomonas stutzeri due to its great capability in completing nitrate elimination, removing $3 \mathrm{~g} / \mathrm{L}$ (as $\mathrm{KNO}_{3}$ ) in just $48 \mathrm{~h}$, and its effectiveness on artworks when nitrate biocleaning strategies are applied $[8,16,22,26-28]$. Pseudomonas stutzeri is an aerobic, non-sporulating, gram-negative soil bacterium widely distributed in the environment. It is classified as a risk group 1 bacterium (according to the CECT classification and based on INSHT(National Institute of Safety and Hygiene at Work (Instituto Nacional de Seguridad e Higiene en el Trabajo)) technical guide), which means that there is a low individual and community risk and is, therefore, unlikely to cause disease. Even though there was a low risk, and it has rarely been reported, by itself, in relation to affecting patients or causing human disease (only in combination with other microorganisms and on patients with serious underlying disease) [29], it was important that restorers put in place extreme precautions using a safe handling procedure. When applying the biocleaning technologies we took into account that we were working with living microorganisms, and paid special attention when handling the bacteria and with the correct management of the bio-treatment residuals. The safe handling procedure included the use of personal protection equipment such as working gloves and a lab coat [2].

Once the biocleaning bacteria was selected and the stone pathology characterized, the application protocol was optimized according to two important factors required for the microorganisms to act: temperature and water. Temperature is one of the most important factors conditioning the growth of microorganisms as well as the efficiency of the denitrify- 
ing process needed for the bio-desalination to occur [28]. So, in situ high dimension heating systems are needed for the treatment and the optimal and constant temperature must be established while also taking into account cost-efficient features. Water is essential for the viability of the microorganisms and, therefore, for a correct bio-desalination process, but it can also produce material alterations [16,30]. Previous biocleaning studies have shown that minimal water has been enough for the process to succeed so, therefore, the use of a water-based gel appeared to be the best option [31,32].

According to the abovementioned factors, this work analyzes in situ three water-based gel delivery systems and three heating systems and evaluates them in terms of in situ performance difficulty, efficacy, and costs, allowing us to implement an innovative and optimized in situ high scale bio-desalination application protocol.

\section{Materials and Methods}

\subsection{Site Description}

The pavement object of this study is in the Cristo Chapel of the Santa María de Conxo Church, located in Santiago de Compostela, Spain. It is a Baroque construction (17th century) with original granite ashlar walls and vaults. The flooring is composed of $233 \mathrm{~m}^{2}$ of approximately $15 \mathrm{~cm}$ thick granite slabs that rest directly on the ground and whose joins are mostly open. Some of the slabs constitute burial covers. The Chapel also has a cemetery on its north side, with niches attached to the facade of this orientation.

\subsection{Pseudomonas Stutzeri Optimal Denitrification Assessment}

Pseudomonas stutzeri, strain 930T (CECT), nitrate-reducing bacterium was selected due to its complete denitrification capacity and its wide use in biocleaning strategies $[8,16,22,26-$ 28]. The complete denitrification process consisted of a stepwise process of nitrate $\left(\mathrm{NO}_{3}{ }^{-}\right)$ reduction to nitrite $\left(\mathrm{NO}_{2}{ }^{-}\right)$and then to nitrogen $\left(\mathrm{N}_{2}\right)$ gas [33].

In order to determine the optimal time and temperature for its complete denitrification activity, in vitro analysis was carried out. One colony of Pseudomonas stutzeri 930T (CECT) was inoculated in $10 \mathrm{~mL}$ Nitrate Broth cultivation media (Scharlau SL) tubes and incubated at the three temperatures tested: $4{ }^{\circ} \mathrm{C}, 20^{\circ} \mathrm{C}$, and $26^{\circ} \mathrm{C}$.

The denitrification process was tracked using Nitrate and Nitrite test strips (Quantofix, Macherey-Nagel GmbH \& Co, Düren, Germany) and the presence of nitrogen gas formation by its entrapment in Durham chamber after $24 \mathrm{~h}, 48 \mathrm{~h}$ and $72 \mathrm{~h}$ of incubation time. Turbidity and total number of viable bacteria in the tests was determined by serial dilutions and colony forming units (UFU) $\mathrm{mL}^{-1}$ counts $[8,16,28]$. As a negative control, tubes without bacteria were also analyzed. Tests were conducted in triplicate.

\subsection{Biomass Production}

Pseudomonas stutzeri, strain 930T (CECT) nitrate-reducing biomass production was carried out in $2 \times 5 \mathrm{~L}$ of sterile Nitrate Broth (Scharlau SL) cultivation media. Five vol.\% of seed culture was inoculated and incubated for $48 \mathrm{~h}$ at $28^{\circ} \mathrm{C}$ under aerobic conditions, adapting the protocol of Vidakovik et al. (2019) [28]. The Nitrate Broth cultivation media consisted of: meat extract $(3 \mathrm{~g} / \mathrm{L})$, peptone $(5 \mathrm{~g} / \mathrm{L})$, and potassium nitrate $(1 \mathrm{~g} / \mathrm{L})$. The $10 \mathrm{~L}$ bacteria suspension was centrifugated $\left(6000 \mathrm{rpm}\right.$ for $10 \mathrm{~min}$, Beckman Coulter Avanti ${ }^{\mathrm{TM}}$ J-25 high performance centrifuge, Beckman instruments, Palo Alto, CA, USA, EEUU). The pellet was washed with $\mathrm{NaCl}(0.8 \% \mathrm{pH} 7.0)$ and re-suspended in 6 tubes with $50 \mathrm{~mL}$ mineral water. Tubes were sent by $24 \mathrm{~h}$ refrigerated courier at $4-8{ }^{\circ} \mathrm{C}$ to the church for their application. Once in the church, $3 \times 50 \mathrm{~mL}$ tubes were diluted with $4850 \mathrm{~mL}$ of mineral water to obtain the $5000 \mathrm{~mL}$ of application suspension with a final bacterial concentration of approximately $10^{10}$ colony forming units (CFU) $\mathrm{mL}^{-1}$. A final volume of application suspension of $10 \mathrm{~L}$ was obtained, which allowed for $30 \mathrm{~m}^{2}$ bio-desalination. In order to be able to bio-desalinate the complete pavement of $233 \mathrm{~m}^{2}$, eight cycles of bacterial preparation and shipping were needed. 


\subsection{High Scale Application Protocol Implementation}

In order to correctly conduct the bio-desalination on high dimension pavement, the bio-desalination application protocol was implemented.

This was based on the assessed optimal denitrification conditions of P. stutzeri (see Sections 2.1 and 3.1) and on the previously conducted in vitro and in situ preliminary biodesalination small tests conducted in the lab and in the church and published previously [8]. The protocol was defined as follows: $48 \mathrm{~h}$ application time, $2 \%$ agar as delivery system, and $26 \pm 4{ }^{\circ} \mathrm{C}$ as the optimal pavement temperature for bacterial denitrification.

Three delivery systems were tested: warm 2\% agar (AgarArt, C.T.S. España S.L, Madrid, Spain), ground 2\% agar (AgarArt, C.T.S. España S.L., Madrid, Spain), and Nevek ${ }^{\circledR}$ (C.T.S. España S.L., Madrid, Spain). Agar is a complex polysaccharide extracted from red algae, soluble in water, and able to produce gels with no liquid water release. It is widely used in restoration, including cleaning and salt extract processes because it is able to limit the water release onto artistic surfaces [30]. In order to use it in the restoration field it can be acquired commercially in two main consistencies: as a powder (AgarArt) or as a pseudo-gel (namely Nevek ${ }^{\circledR}$ ). The first type must be mixed with water and boiled in order to be used and the second can be applied direct from the storage package.

The tested delivery systems preparation protocols are as follows:

- Warm $2 \%$ agar is prepared by mixing $2 \%$ agar powder in deionized water and then boiling it. Then, it must be tempered (between $40-45^{\circ} \mathrm{C}$ ) to become a semisolid, which is a good consistency for the application.

- Ground $2 \%$ agar is previously prepared in the lab following the warm agar protocol but leaving to become completely cold and, therefore, to jellify on a crystal recipient. Then it is ground and used or stored in a fridge for a few hours.

- $\quad \operatorname{Nevek}^{\circledR}$ does not need any preparation because it is directly applied from the storage package.

Three thermic systems were tested: infrared heat lamps (Massive Halo R7s, Zenith CT, Italy; with $300 \mathrm{~W}$ halogen bulb, Lexman R7s, Leroy Merlin España S.L.U., Valencia, Spain), air heater (Honeywell $2.000 \mathrm{~W}$, Charlotte, NC, USA), and heating electric mat (Al $140 \mathrm{~W} / \mathrm{m}^{2}$, CEILHIT SLU, Barcelona, Spain). These thermic systems selected augment the temperature in different ways. Infrared heat lamps contain an incandescent bulb that produces infrared radiation causing heat and increasing the temperature of the object that is being heated. Air heater works by passing an air flow across a heated element (coil of wire that by passing electrical current through it, heat is produced) that augments the air flow temperature. Heating electric mat is composed of a mat with a thin electric heating wire stuck on it. The wire heats the material directly in contact with the mat rather than warming the air.

The tested thermic systems preparation protocols are as follows:

- Infrared heat lamps are installed onto a tripod and oriented to face the treatment surface. They must be switched on for $14 \mathrm{~h}$ before treatment in order to reach the desired treatment temperature. The surface temperature is manually measured with an infrared thermometer (Parkside PTIA1, OWIM GmbH \& Co. KG, Neckarsulm, Germany).

- The air heater must be inserted into a previously installed hothouse on the treated area in order to reduce the volume of air to be warmed. The air heater must be activated $24 \mathrm{~h}$ before treatment in order to obtain the adequate treatment temperature. The surface temperature is manually measured with an infrared thermometer.

- A heating electric mat (10 $\mathrm{m}$ long and $50 \mathrm{~cm}$ wide, Warmup, $\mathrm{UK}$ ) is applied directly to the delivery system and, on top of the mat, a thermally insulating material (such as wood panels) must be added in order to avoid temperature loss to the ambient air. The heating electric mat must be activated $24 \mathrm{~h}$ before treatment in order to obtain the desired temperature. It has a temperature control thermostat.

In order to identify the optimal protocol, in situ application trials were conducted (Figure 1) and were analyzed in terms of: performance difficulty including: preparation 
difficulties, supporting equipment, preparation and application time; efficiency application and removal complexity; temperature and humidity (moisture meter, Stanley ${ }^{\circledR}$ STHT 77030, Stanley Black \& Decker, Victoria, Australia) efficacy, and homogeneity; economic evaluation (material costs, energy consumption). After their evaluation, the best performing delivery systems and the best performing thermic systems were applied in situ to the whole chapel pavement (Section 2.4). Bio-desalination was monitored over time (after 1 and 12 months) by efficiency evaluation (Section 2.5) and visual cleaning was measured by digital image analysis (Section 2.6).

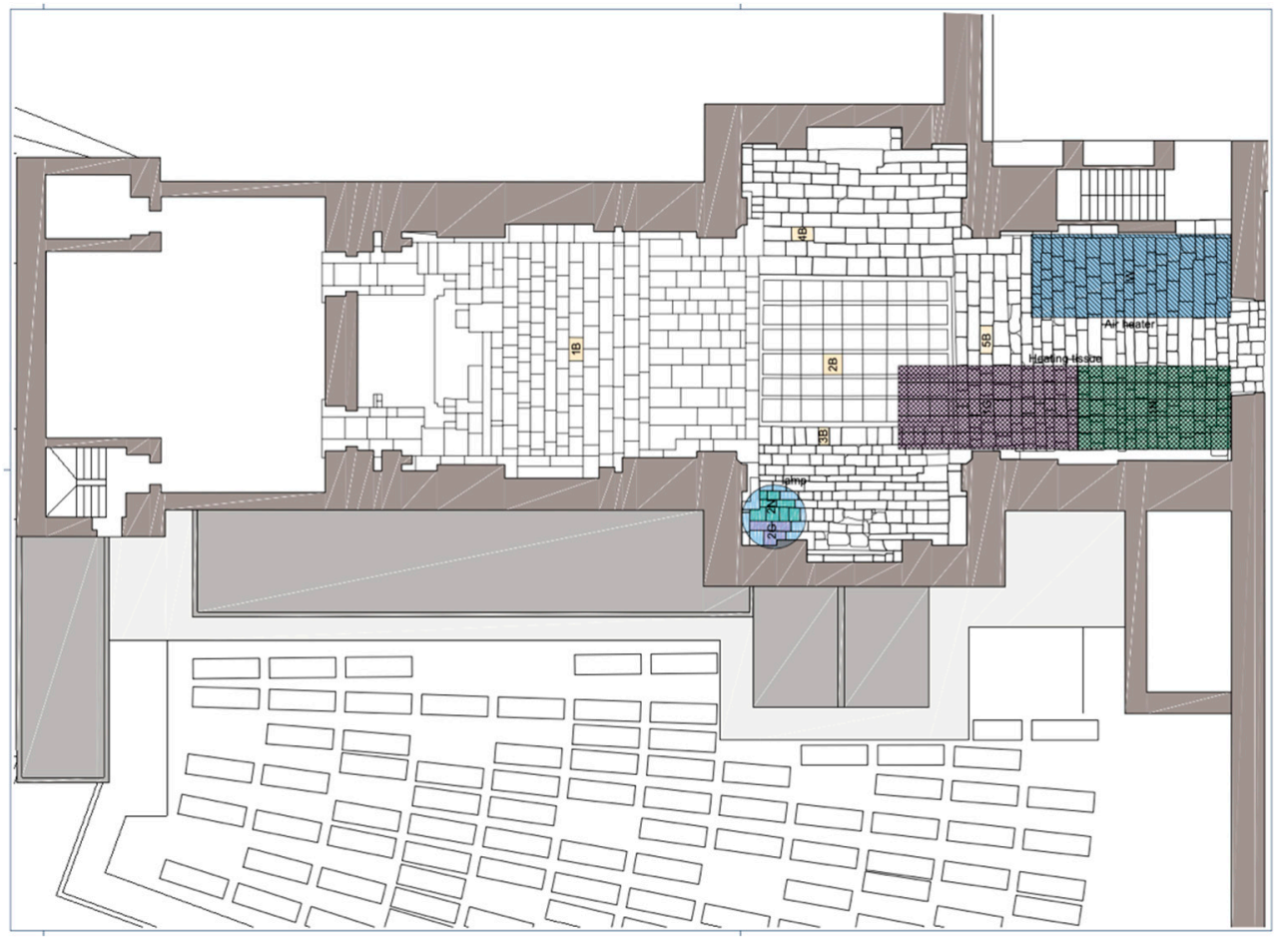

Figure 1. Cristo chapel plan (provided by Raquel Otero and Lourdes Pérez) showing the granite slabs. In situ preliminary test areas are marked. Tested thermic systems (lamp, air heater, and heating mat) and tested delivery systems; N: $\operatorname{Nevek}^{\circledR} ; \mathrm{W}$ : warm $2 \%$ agar; G: ground $2 \%$ agar. Selected slabs $(1 \mathrm{~B}, 2 \mathrm{~B}, 3 \mathrm{~B}, 4 \mathrm{~B}, 5 \mathrm{~B})$ used for final bio-desalination monitoring tests are marked in yellow.

\subsection{High Scale Optimized Protocol}

Bio-desalination of the whole chapel pavement was conducted with Pseudomonas stutzeri CECT 930T (prepared as described in Section 2.2) and with the optimized application protocol selected according to the best performing and most efficient delivery system and thermic system (Section 2.3).

The application protocol consisted of application of the bacterial suspension directly to the pavement with a sterile brush. Then, Japanese paper was applied to facilitate the removal of the delivery system. After the delivery system was placed onto the surface, a plastic film (food plastic wrap) was later applied to cover the application treatment to avoid water evaporation and drying of the agar. Finally, the thermic system was applied, and the bio-desalination treatment was left for $48 \mathrm{~h}$.

After treatment, the thermic system was switched off and removed. The plastic film, delivery system, and Japanese paper were removed, and the treated surface was cleaned using a sponge humidified with deionized water to remove bacterial cells and agar rests from the treated surface. Then, the treated surface was left to dry naturally [16]. Finally, the bio-desalination treatment was monitored over time (as described in Sections 2.5 and 2.6).

All the processed were carried out with the use of personal protection equipment such as working gloves and lab coat. All the residuals from the bio-desalination treatment 
(including bacterial suspensions, supported equipment in direct contact with bacteria, etc.) were sanitized by addition of bleach or cleaning with ethanol $70 \%$.

\subsection{Bio-Desalination Monitoring}

The high dimension bio-desalination of the church was monitored on 5 slabs corresponding to north (3B), south (4B), east (1B), west (5B), and center (2B) of the chapel (Figure 1).

Bio-desalination efficiency monitoring consisted of measuring, on each selected slab, salt reduction, nitrate-nitrite reduction, and microbial presence. Monitoring was evaluated 1 and 12 months after the bio-desalination treatment in order to evaluate short-term and long-term effects of the treatment.

Salt reduction was measured by ionic conductivity (HANNA DiST3 H198303 EC Tester, Hanna Instruments S.L., Eibar, Spain). A circular (7 cm diameter) $50 \mathrm{~g}$ cellulose paper (Arbocel ${ }^{\circledR}$ BC 1000, Kremer Pigmente, Germany) was applied to each slab. Deionized water $(4: 1 \mathrm{wt} / \mathrm{wt})$ was added and left for $10 \mathrm{~min}$. Then, the cellulose paper was introduced into a recipient, and deionized water was added (until a final weight of $90 \mathrm{~g}$ ), left for $1 \mathrm{~h}$, and liquid conductivity was measured [34]. The conductivity of deionized water $(5.8 \mu \mathrm{S} / \mathrm{cm}$ media values approximately) was subtracted from the test data. Each ion conductivity measurement was completed in triplicate.

Nitrate reduction was measured by semi-quantitative colorimetric nitrate-nitrite tests (Quantofix, Macherery-Nagel GmbH \& Co, Düren, Germany). Nitrate-nitrite tests were introduced in the abovementioned recipient for $1 \mathrm{~s}$. Then, tests were left at room temperature for $1 \mathrm{~min}$, and the strip color was compared to the manufacturer's color scale, allowing for the nitrate and nitrite content ( $\mathrm{ppm}$ ) to be determined. The Quantofix tests sensibility values are between $10-500 \mathrm{mg} / \mathrm{L}$ for nitrates and between $1-80 \mathrm{mg} / \mathrm{L}$ for nitrites.

Microbial presence was analyzed by sterile swab sampling before and after the biodesalination treatment. Each swab was then suspended in sterile $0.9 \% \mathrm{NaCl}$ and $0.5 \mathrm{~mL}$ of the suspension was placed on a petri dish with nutrient agar (for bacteria) and sabouraud chloramphenicol agar (for fungi) and incubated at $28^{\circ} \mathrm{C}$ for $48 \mathrm{~h}$ and 5 days, respectively. Bacteria and fungi colonies were counted and expressed in CFU per $25 \mathrm{~cm}^{2}$.

\subsection{Digital Analysis Cleaning Study}

In order to confirm that the bio-desalination treatment corresponds with pavement cleaning, the relative percentage of cleanliness achieved was estimated by digital analysis of the images obtained before and after treatment.

The digital image analysis was based on the specific software scheme and method in MatLab (Matrix Laboratory) [8] with the necessary modifications to estimate the percentage of cleanliness from a cleaned slab selected as ideally clean.

For each five selected slabs (1B, 2B, 3B, 4B, 5B), three images were analyzed: before, after, and follow-up (one year after) treatment.

The images were captured as standardized as possible with a digital camera (NIKON D5100) under fixed conditions (ISO100, f/8.0, 1/250 s, focal length $19 \mathrm{~mm}$ ) on a tripod and the same blue cardboard template, as a reference for the lighting correction. An automatic segmentation by thresholding of the Hue, Saturation, and Value (HSV) components, a morphological processing to obtain the masks of the area of interest and reference, as well as a correction of the luminosity of the images by homogenizing the images after the treatment with those before it, were carried out.

Finally, the results obtained were shown by means of different graphical representations, calculating the median, standard deviation, and outliers for each image. A cleaned slab, representing an ideally clean slab, and a corresponding slab before treatment were chosen as a common reference of $100 \%$ and $0 \%$ cleanliness, respectively. 


\section{Results}

\subsection{Selection of Best Bacterial Denitrification Conditions}

As shown in Table 1 , the process of denitrification was absent at $4{ }^{\circ} \mathrm{C}$ temperature at the three studied times, because bacterial growth was almost inhibited. At $20^{\circ} \mathrm{C}$, the denitrification process needed $48 \mathrm{~h}$ incubation time to occur, while at $26^{\circ} \mathrm{C}$ the process started after a $24 \mathrm{~h}$ incubation period. This denitrification process was noticed by the reduction of nitrates and nitrite content and the formation of gas in Durham chambers.

Table 1. Denitrification of P. stutzeri $930 \mathrm{~T}(\mathrm{CECT})$ at $4{ }^{\circ} \mathrm{C}, 20^{\circ} \mathrm{C}$, and $26^{\circ} \mathrm{C}$.

\begin{tabular}{ccccccc}
\hline Time (h) & $\begin{array}{c}\text { Temperature } \\
\left({ }^{\circ} \mathbf{C}\right)\end{array}$ & $\begin{array}{c}\text { Turbidity } \\
(+/-)\end{array}$ & CFU mL $^{-\mathbf{1}}$ & $\begin{array}{c}\text { Nitrates } \\
\left(\mathbf{m g ~ L}^{-1}\right)\end{array}$ & $\begin{array}{c}\text { Nitrites } \\
\left(\mathbf{m g ~ L}^{-\mathbf{1}}\right)\end{array}$ & Gas (+/-) \\
\hline \multirow{2}{*}{24} & 4 & - & $2.0 \times 10^{1}$ & 500 & 23 & - \\
& 20 & - & $2.0 \times 10^{2}$ & 500 & 18 & - \\
48 & 26 & + & $8.0 \times 10^{3}$ & 0 & 77 & + \\
& 4 & - & $1.0 \times 10^{2}$ & 500 & 24 & - \\
72 & 20 & + & $3.0 \times 10^{6}$ & 0 & 63 & + \\
& 26 & + & $1.0 \times 10^{5}$ & 0 & 64 & + \\
& 4 & - & $1.9 \times 10^{2}$ & 500 & 26 & - \\
& 20 & + & $3.0 \times 10^{6}$ & 0 & 66 & + \\
\hline
\end{tabular}

+ , presence of turbidity in the $10 \mathrm{~mL}$ nitrate broth medium tubes; or presence of nitrogen gas formation in the Durham chamber. -, absence of turbidity in the $10 \mathrm{~mL}$ nitrate broth medium tubes; or absence of nitrogen gas formation in the Durham chamber. CFU mL $\mathrm{m}^{-1}$, colony forming units of $P$. stutzeri in the nitrate broth medium tubes.

These results agree with other authors' results that demonstrate that $P$. stutzeri needs between an 8 to $24 \mathrm{~h}$ incubation period to start denitrification and then was able to complete nitrate elimination of $3 \mathrm{~g} / \mathrm{L}\left(\mathrm{as}_{\mathrm{KNO}}\right)$ in just $48 \mathrm{~h}$ [28].

Negative controls at the three studied temperatures and times showed constant nitrate and nitrite levels (500 $\pm 0 \mathrm{mg} \mathrm{L}^{-1}$ and $20 \pm 6 \mathrm{mg}^{-1}$, respectively) and absence of gas and microbial growth (negative turbidity and absence of $\mathrm{CFU} \mathrm{mL} \mathrm{m}^{-1}$ ).

\subsection{Optimal High Scale Application Protocol Determination}

The bio-desalination application protocol was implemented in order to be able to efficiently treat the $233 \mathrm{~m}^{2}$ of the pavement. This was based on the bio-desalination application protocol described in the preliminary small tests conducted in the church [8]. That protocol defined the application time $(48 \mathrm{~h})$, the delivery system $(2 \%$ agar $)$, and the optimal pavement temperature for bacterial denitrification $\left(26 \pm 4^{\circ} \mathrm{C}\right)$. While up-scaling the process, two critical points were identified and optimized: (i) the delivery system was applicable and easy to use on big, in situ surfaces; (ii) thermic systems were constant and adequate for maintaining homogeneous pavement temperature during treatment.

According to previous studies, agar was selected as a delivery system [8,30], but three different types of agar were tested: warm $2 \%$ agar, ground $2 \%$ agar, and $\mathrm{Nevek}^{\circledR}$ (Figure 2A, Figure 2B, and Figure 2C, respectively).

From the three delivery systems tested, warm $2 \%$ agar was the first to be tested, according to previous results conducted in the chapel on a smaller scale [8]. When up-scaling the in situ application dimensions, warm $2 \%$ agar showed the highest high dimension in situ performance difficulties (Table 2). This implies very high preparation difficulties that included the need for many supporting pieces of equipment. Once the agar is weighed and diluted in water, it must be boiled; therefore, a microwave or electric heater is needed. Then, before adding the warm agar to the pavement, the warm agar must be adjusted to about $45^{\circ} \mathrm{C}$, the application temperature. Adjusting the agar temperature is a very delicate task because there is a small temperature range where it can be correctly used in biocleaning; if it is too hot, bacteria will die, and if it gets too cold, it will jellify and will not be correctly adapted to the rough granite surface. Therefore, this process must be constantly monitored by a thermometer, and warm agar must be mixed constantly in 
order to allow for a correct homogeneous temperature. This is a very personnel-consuming process because two persons must work together in order to properly prepare and apply the warm agar. This high time-consuming process can be accelerated by cooling the agar with a cooled (with ice and salt) water bath. During this process (heating and cooling of the agar), a lot of water vapor is generated, which is detrimental to the environment of the church, which already has a high level of humidity. The application is also a delicate step because it must be quickly applied (in order to avoid the agar from jellifying) and, due to its liquid state, it can go over the treatment area. In order to limit the treatment area and avoid the warm agar from entering the gaps between the slabs, cellulose can be added to restrict the border (see Figure 2A), but it must be removed just after the agar application because if it is left on the pavement for a few days, fungi will grow on it due to the high air humidity. All these performance difficulties significantly reduced the quantity of square meters able to be treated in a day, up to $15 \mathrm{~m}^{2}$, and augmented the economic costs. Personnel costs were the highest evaluated because there was a need for two persons working together for $2.4 \mathrm{~h}$ in order to bio-desalinate $1 \mathrm{~m}^{2}$. Material costs included higher agar requirements $\left(152 \mathrm{~g} / \mathrm{m}^{2}\right)$ compared to $2 \%$ ground agar $\left(52 \mathrm{~g} / \mathrm{m}^{2}\right)$ because a significant quantity of agar jellified on the different recipients used in the preparation and application process. Due to all of the high in situ performance difficulties observed, warm $2 \%$ agar was discarded for high dimension bio-desalination, and ground $2 \%$ agar and Nevek ${ }^{\circledR}$ were tested next.
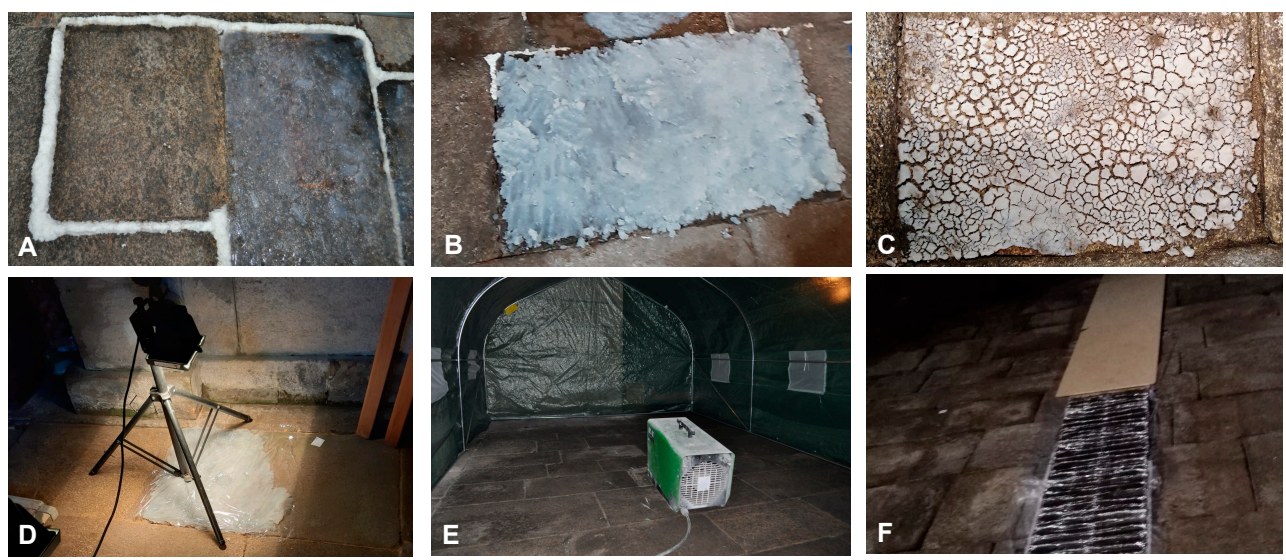

Figure 2. Image showing the delivery systems and thermic systems tested. (A): warm $2 \%$ agar; (B): ground $2 \%$ agar; (C): Nevek $^{\circledR} ;($ D): infrared heat lamps; $($ E): air heater; $(\mathbf{F})$ : heating electric mat.

Table 2. High scale onsite bio-desalination application protocol evaluation.

\begin{tabular}{|c|c|c|c|c|c|c|c|c|c|}
\hline & & \multicolumn{6}{|c|}{ In Situ Performance Difficulties } & \multirow{2}{*}{\multicolumn{2}{|c|}{$\begin{array}{c}\text { Economic Evaluation } \\
\text { Costs } € / \mathrm{m}^{2}(4)\end{array}$}} \\
\hline & & \multirow{2}{*}{$\begin{array}{l}\text { Preparation } \\
\text { Difficulties }\end{array}$} & \multirow{2}{*}{$\begin{array}{l}\text { Supporting } \\
\text { Equipment }\end{array}$} & \multirow{2}{*}{$\begin{array}{c}\text { Time-Consuming } \\
\text { (1) }\end{array}$} & \multirow{2}{*}{$\begin{array}{l}\text { Efficiency } \\
\text { (2) }\end{array}$} & \multirow{2}{*}{ Complexity } & \multirow{2}{*}{$\begin{array}{l}\text { Treatment } \\
\text { Area/Day }\end{array}$} & & \\
\hline & & & & & & & & Material (5) & Personnel (6) \\
\hline \multirow{3}{*}{$\begin{array}{l}\text { Delivery } \\
\text { system }\end{array}$} & Warm $2 \%$ agar & very high & very high & very high & very high & medium & $15 \mathrm{~m}^{2}$ & EUR 11.91 & EUR 104.98 \\
\hline & $\begin{array}{c}\text { Ground 2\% } \\
\text { agar }\end{array}$ & low & low & medium & very high & low & $30 \mathrm{~m}^{2}$ & EUR 7.42 & EUR 18.37 \\
\hline & Nevek & low & low & low & medium & low & $30 \mathrm{~m}^{2}$ & EUR 70.66 & EUR 14.00 \\
\hline \multirow{3}{*}{$\begin{array}{l}\text { Thermic } \\
\text { systems }\end{array}$} & $\begin{array}{l}\text { Infrared heat } \\
\text { lamps }\end{array}$ & high & high & medium & very low & high & $15 \mathrm{~m}^{2}$ & EUR 3.54 & EUR 2.53 \\
\hline & Air heater & high & high & high & low & high & $15 \mathrm{~m}^{2}$ & EUR 7.40 & EUR 1.56 \\
\hline & $\begin{array}{c}\text { Heating } \\
\text { electric mat }\end{array}$ & medium & medium & medium & very high & medium & $25 \mathrm{~m}^{2}$ & EUR 13.49 & EUR 0.98 \\
\hline
\end{tabular}

Evaluation criteria: absence; low; medium; high; very high; (1) Includes preparation, application, and removal time (2) Efficiency is related to the correct, homogeneous and constant water and temperature needed to be achieved by the thermic systems and the delivery system (3) Includes application and removal complexity (4) Costs do not include company overheads, industrial profit, or VAT. (5) Refers only to the materials needed for the application, including the delivery and thermic systems and the complementary materials (cellulose, deionized water, plastic film, Japanese paper, wood panels, hothouse, etc. and does not include bacterial cells) for the delivery system; and in the case of the thermal systems, it refers to the cost of renting the equipment and its power supply. (6) Personnel costs for the whole process including preparation, application, and removal for the delivery system and assembly and disassembly of the thermic systems. 
Ground 2\% agar significantly reduces the high dimension, in situ performance difficulties because it is directly applied to the pavement without any in situ preparations (agar preparation is completed previously in the laboratory). There is no need for in situ supporting equipment, and application and removal is easy and with medium time-consumption. Higher areas, up to $30 \mathrm{~m}^{2}$, can be treated in a day, and economic costs are reduced both in terms of material and personnel costs $\left(0.84 \mathrm{~h}\right.$ for $\left.1 \mathrm{~m}^{2}\right)$. Similar performance occurs with Nevek $^{\circledR}$, which also has low preparation difficulties (because it is applied directly from the original package), low supporting equipment, low time-consumption, and low application and removal complexity, also allowing for a $30 \mathrm{~m}^{2}$ treatment area in a day. Economic costs are higher because, even though the personnel costs are low $\left(0.64 \mathrm{~h}\right.$ for $\left.1 \mathrm{~m}^{2}\right)$, the material costs are very high as $3.3 \mathrm{~kg}$ of product is needed to bio-desalinate $1 \mathrm{~m}^{2}$.

In regard to the delivery system efficiency, both warm and ground agar showed very high efficiency by supplying high (100\% humidity) and homogeneous water to the surface (as needed for the microorganisms to clean). Instead, Nevek ${ }^{\circledR}$, after the $48 \mathrm{~h}$ treatment time, showed excessive drying and the presence of significant cracks that increased when thermic systems were added (see Figure 2C). This could interfere with the correct and homogeneous biocleaning process and even complicate the removal. In order to avoid this, a thicker layer of Nevek $^{\circledR}$ could be added, which implies an increase in economic costs.

These preliminary in situ delivery system trials allowed us to discard the use of warm $2 \%$ agar for high dimension surfaces bio-desalination application due to the high in situ performance difficulties observed, and to discard Nevek ${ }^{\circledR}$ due to the high economic costs and excessive drying. Ground 2\% agar was selected as the best performing delivery system.

In addition, three thermic systems were tested: infrared heat lamps, an air heater, and a heating electric mat (Figure 2D, Figure 2E, Figure 2F, respectively). Infrared heat lamps were selected because they have previously been used in biocleaning studies [8,13,15-17]. The other thermic systems, tested here for the first time, were selected due to their potential ability to warm high dimension areas. Again, in situ performance difficulties, thermal efficiency, and economic costs were evaluated and compared (Table 2).

From the three thermic systems tested, the air heater had the highest in situ performance difficulty (see Table 2). Preparation and removal was tedious, complex, time consuming, and significant supporting materials were needed (a hothouse had to be installed on the treated area in order to reduce the volume of air to be warmed, which complicated the application on non-orthogonal areas and reduced the quantity of square meters able to be treated in a day, up to $15 \mathrm{~m}^{2}$ in this case). Thermal efficiency was very low because the system needed about $24 \mathrm{~h}$ to reach the required average air temperature of $26 \pm 6{ }^{\circ} \mathrm{C}$. Additionally, the temperature was not homogeneous on the treated area, with high temperatures (about $30^{\circ} \mathrm{C}$ ) on the areas near the air heater and low temperatures (about $20^{\circ} \mathrm{C}$ ) on the areas far from the air heater. In addition, it was found that the heating of the hothouse air caused an increase in its capacity to contain water vapor and caused an increase in soil evaporation, dragging the existing salts inside the slabs towards its surface, and producing, again, darkening of the slabs. Economic evaluation showed a medium material cost $/ \mathrm{m}^{2}$ and a lower personnel cost $/ \mathrm{m}^{2}$.

Similar high dimension drawbacks were observed with the infrared heat lamp. The lamps had to be switched on $14 \mathrm{~h}$ before treatment in order to get the pavement temperature to $26^{\circ} \mathrm{C}$, but after $24 \mathrm{~h}$ treatment, the pavement temperature increased to $29{ }^{\circ} \mathrm{C}$, and at the end of the treatment $(48 \mathrm{~h})$, the pavement temperature was $35^{\circ} \mathrm{C}$. In addition, the temperature was not homogeneous on the area illuminated with the lamps because it depended on the light beam, which was stronger in the central area and weaker at the edges. This inhomogeneous temperature can influence the bacterial desalination (even though the bacteria are viable within those temperatures, the enzymatic kinetics augment with temperature) and the water content of the delivery system by drying it completely in some areas and making its removal much more difficult [28]. The bio-desalination process could also completely stop. The in situ preparation performance on high dimensions was also difficult, with medium time-consumption, and needing supporting equipment. 
The system needed a structure to be assembled (like a mobile scaffolding) to allow for the assembly of different lamps that covered a bigger area. Both systems, due to their limitations, did not allow for a homogenous, high treatment area to be completed in a day. Economic evaluation shows a lower costs of material but a higher personnel costs.

The heating electric mat showed medium onsite performance difficulties because the pavement had to be covered with the heating mat $24 \mathrm{~h}$ previous to treatment, and it had to be raised in order to add the treatment. On the top of the mat, a thermal insulating material had to be added in order to avoid temperature loss. Nevertheless, it showed a very high thermic efficiency (constant $26^{\circ} \mathrm{C}$ temperature was measured on the granite pavement surface) and allowed for coverage over large areas. The mat was easily and perfectly adapted to the church space because the mat could be cut according to the dimensions of the space (as long as the electric radiant wire was not cut). The mat was the most versatile, easy, and comfortable to use in high dimension treatments. The system allowed one person to perform a $25 \mathrm{~m}^{2}$ treatment area per day. The total costs per square meter were about double the costs of the lamps and the air heater, but the thermic benefits and the convenience and simplicity of its in situ performance were considered worthwhile.

According to these results, the high dimension bio-desalination protocol was optimized by selecting ground $2 \%$ agar in combination with a heating electric mat as the best performing delivery system and thermic system. Therefore, the optimized protocol (Figure 3) was applied to the $233 \mathrm{~m}^{2}$ of the chapel pavement.

\subsection{Efficiency of High Dimension Bio-Desalination}

Before and after the bio-desalination treatment, ion conductivity, nitrate-nitrite reduction, and microbial presence was measured for the selected five slabs.

One month after the bio-desalination high dimension treatment, a significant salt reduction was observed in all of the slabs (Table 3), with mean values of $31.1 \%$, which was maintained in most of the slabs during the following 12 months (follow-up).
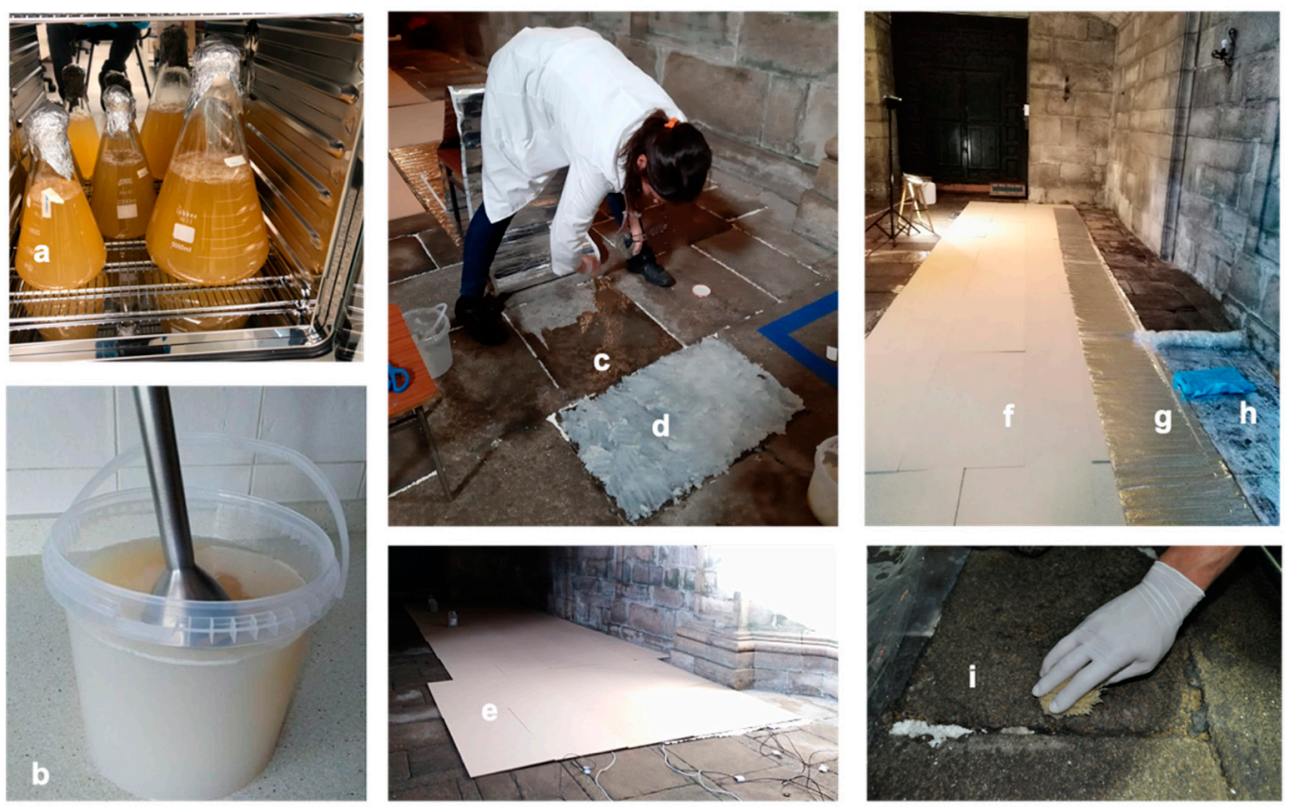

Figure 3. High dimension bio-desalination optimized protocol applied to the $233 \mathrm{~m}^{2}$ church granite pavement. In lab preparation: (a) bacterial biomass production; (b) $2 \%$ ground agar preparation. In situ application: (c) bacterial application; (d) $2 \%$ ground agar application over the Japanese paper; (e) thermic mat applied and insulating wood panels. After treatment: removal of (f) wood panels; (g) thermic mat; (h) plastic film, ground agar, and Japanese paper; (i) final cleaning with deionized water and sponge. 
Table 3. High dimension bio-desalination treatment Ion conductivity monitoring.

\begin{tabular}{cccc}
\hline Treated Slab & \multicolumn{3}{c}{ Ion Conductivity $(\boldsymbol{\mu S} / \mathbf{c m})$} \\
\hline 33 & Before & After $^{\mathbf{1}}$ & Follow-Up $^{\mathbf{2}}$ \\
40 & 659 & 387 & 350 \\
41 & 413 & 208 & 303 \\
45 & 423 & 300 & 390 \\
46 & 287 & 252 & 200 \\
Mean values & 282 & 216 & 350 \\
Standard deviation & 412.8 & 272.6 & 318.6 \\
\hline
\end{tabular}

${ }^{1}$ One month after bio-desalination treatment. ${ }^{2}$ Twelve months after bio-desalination treatment.

In order to determine if the salt reduction observed was correlated to a nitrate and nitrite reduction, an in situ analysis was performed on the same slabs before and one month after the bio-desalination treatment (Table 4). Initial values for all of the slabs show the maximal value measured by the test strips $(500 \mathrm{mg} / \mathrm{L}$ for nitrates and $80 \mathrm{mg} / \mathrm{L}$ for nitrites). After the bio-desalination, all slabs showed a reduction in nitrate and nitrite values, with $30 \%$ and $60 \%$ statistically significant reduction rates, respectively ( $p$-values of 0.04 and 0.0001 , respectively). Twelve months after the treatment, the slabs showed an increased reduction in nitrate and nitrite values of up to $58 \%$ and $100 \%$ statistically significant reduction rates, respectively ( $p$-values of 0.000044 ).

Table 4. High dimension bio-desalination treatment nitrate-nitrite reduction monitoring.

\begin{tabular}{|c|c|c|c|c|c|c|}
\hline \multirow{3}{*}{$\begin{array}{c}\text { Treated } \\
\text { Slab }\end{array}$} & \multicolumn{6}{|c|}{ Nitrate-Nitrite Reduction (mg/L) } \\
\hline & \multicolumn{2}{|c|}{ Before } & \multicolumn{2}{|c|}{ After ${ }^{1}$} & \multicolumn{2}{|c|}{ Follow-Up ${ }^{2}$} \\
\hline & Nitrates & Nitrites & Nitrates & Nitrites & Nitrates & Nitrites \\
\hline 33 & 500 & 80 & 250 & 20 & 250 & 0 \\
\hline 40 & 500 & 80 & 500 & 40 & 250 & 0 \\
\hline 41 & 500 & 80 & 250 & 40 & 250 & 0 \\
\hline 45 & 500 & 80 & 250 & 20 & 50 & 0 \\
\hline 46 & 500 & 80 & 500 & 40 & 250 & 0 \\
\hline $\begin{array}{l}\text { Mean } \\
\text { values }\end{array}$ & 500 & 80 & 350 & 32 & 210 & 0 \\
\hline $\begin{array}{l}\text { Standard } \\
\text { deviation }\end{array}$ & 0.0 & 0.0 & 122.3 & 9.8 & 80.0 & 0 \\
\hline
\end{tabular}

${ }^{1}$ One month after bio-desalination treatment. ${ }^{2}$ Twelve months after bio-desalination treatment.

The microbial (bacteria and fungi) presence was also evaluated on the five slabs before and after the bio-desalination treatment. The results showed absence of fungi before and after the bio-desalination treatments and bacteria mean values of $4.7 \pm 2.3 \mathrm{UFC} / 25 \mathrm{~cm}^{2}$ before treatment and $2 \pm 2 \mathrm{UFC} / 25 \mathrm{~cm}^{2}$ after treatment. The difference observed for the bacteria was not significant $(p>0.05)$, indicating that this biocleaning treatment did not significantly alter the CFU content that was present on the chapel pavement. These results agree with the preliminary analysis carried out on the same pavement where contact plates showed very low microbial counts [8].

\subsection{High Dimension Bio-Desalination Visual Cleaning and Digital Imaging Analysis}

After the bio-desalination treatments, a cleaner and clearer surface was visually observed (Figure 4), and no damage of the stone surface was observed. In order to transfer these visual observations into quantifiable data, digital image analysis was used. Digital analysis showed median cleaning percentages of $18.12 \%$ when comparing before and 1 month after the bio-desalination treatment. The cleaning effect was augmented after the 12 months follow-up, reaching median cleaning percentages of $37.78 \%$ (Table 5, Figure 5). 


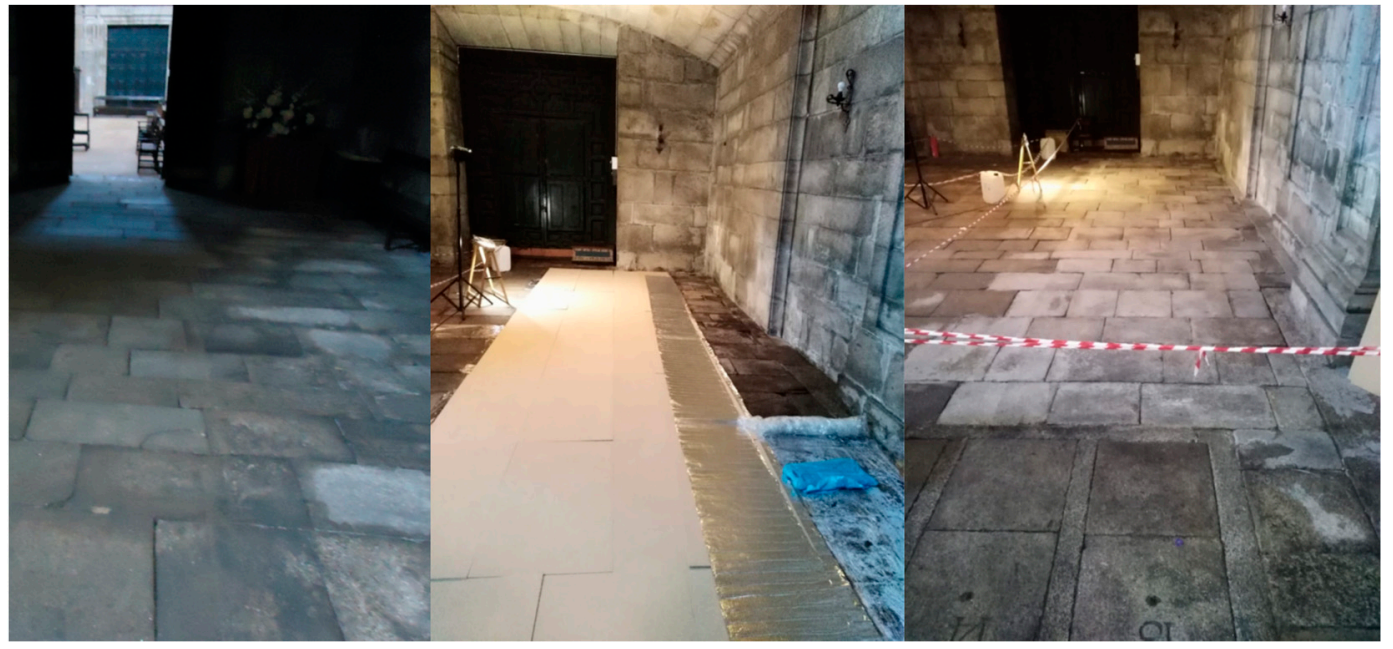

Figure 4. Detail of a church granite pavement $25 \mathrm{~m}^{2}$ treated area following the high dimension bio-desalination optimized protocol. Area before treatment (left image), area during treatment (middle image), and area after treatment (right image).

Table 5. Cleaning percentage of the five slabs selected for high dimension bio-desalination monitoring compared with a $100 \%$ cleaned (ideally cleaned) slab.

\begin{tabular}{ccccccc}
\hline Median \pm std (\%) & 1B & 2B & 3B & 4B & 5B & Media \\
\hline After & $17.80 \pm 21$ & $8.73 \pm 28$ & $24.08 \pm 34$ & $26.30 \pm 28$ & $13.72 \pm 22$ & $18.12 \pm 27$ \\
\hline Follow-up & $28.70 \pm 18$ & $37.05 \pm 25$ & $48.92 \pm 32$ & $56.41 \pm 33$ & $17.85 \pm 22$ & $37.78 \pm 26$ \\
\hline
\end{tabular}

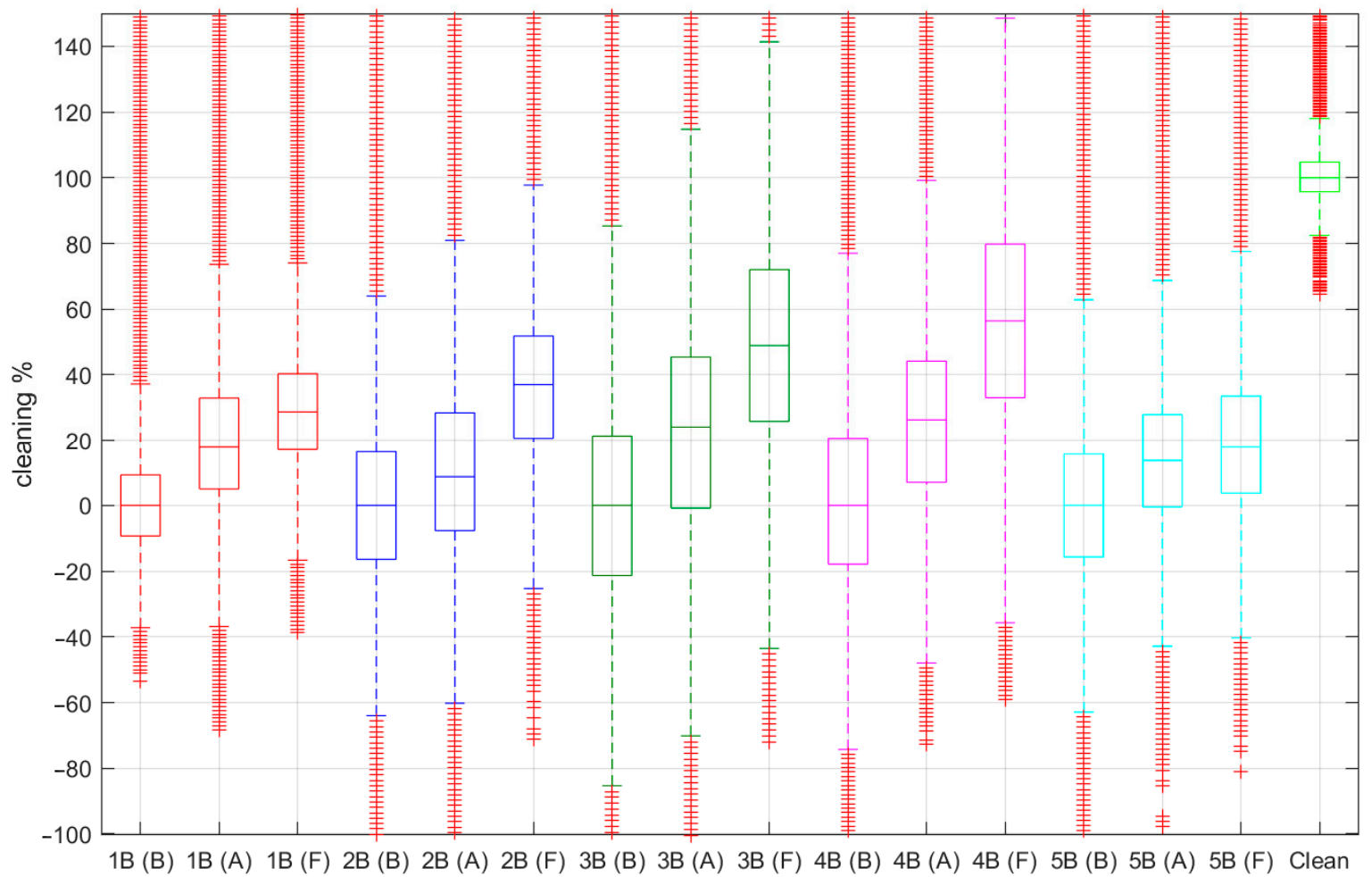

Figure 5. Boxplot showing median, standard deviation, and outliers of the cleaning percentage of the five slabs selected for high dimension bio-desalination of the church monitoring. All values have been adjusted with the control median before treatment $(0 \%)$ and with the clean slab selected as ideally clean $(100 \%)$. For each slab, three measurements were completed: before treatment (B), 1 month after treatment (A), and 12 months after treatment follow-up (F). 


\section{Discussion}

Salt weathering is a global and important deterioration problem for high dimension $\mathrm{CH}$ porous building materials that causes both physical and aesthetic damage and leads to significant cultural and economic consequences. Therefore, in the field of conservation and restoration, many multidisciplinary research teams are focused on understanding this complex and extensive problem in order to find ways to reduce damage caused by salts [34,35]. The most logical and common solution to reduce salt weathering is to reduce the stone salt content [36]. In this sense, bio-desalination has emerged as one possible green conservation solution for this widespread problem by showing real $\mathrm{CH}$ applications with good results on small dimension samples.

Due to the fact that the salt problems usually affect high dimension $\mathrm{CH}$ surfaces, an in situ scale-up implementing study was conducted here.

When working in situ in a $\mathrm{CH}$ building, a church in this particular case study, many important limitations are encountered that do not typically appear when restorations are performed in a laboratory. For example, room temperature cannot be fixed, energy supply/power is frequently low, supporting equipment must be moved in situ, etc. These issues lead to an increase in preparation, application, and removal difficulties, an increase in process time, a reduction in efficiency, a reduction in the treatment area/day, and an increase in costs.

In this study, the scale-up problems that appear when bio-desalination is applied on- site to high dimension $\mathrm{CH}$ surfaces have been identified, evaluated, and overcome. The scale-up problems here identified and evaluated are related to: in situ performance difficulties, efficiency, and economic costs.

In order to reduce in situ high dimension bio-desalination application difficulties, the following suggestions can be followed:

- $\quad$ Reduce in situ material preparation. Any needed preparations must first be completed in the lab to reduce in situ preparation time and equipment.

- Use versatile materials, allowing them to be adapted to the building architectural needs.

- Select materials and protocols that allow a high treatment area per day and selfhandling in order to reduce economic costs.

- Use methods that modify the interior environmental conditions of the monument as little as possible.

- Use electricity generation methods that are compatible with the low electrical power generally supported by the monuments and avoid impact on the surrounding environment (noise, gases, etc.).

In this particular case study, after the evaluation of the critical points identified on the in situ high dimension application protocol, the optimized protocol selected was the use of $2 \%$ ground agar and a heating electric mat (Figure 4 ).

This protocol has low-medium preparation difficulty, use of supporting materials, application complexity, time consumption, and economic costs, and high thermic and water system efficiency as well as good bio-desalination efficacy.

The optimized protocol was applied to the $233 \mathrm{~m}^{2}$ granite pavement, allowing a general salt reduction of up to $31.1 \%$. In particular, as denitrified bacteria were used, nitrates were evaluated, and a 30\% reduction was observed. The visual cleaning observations and measurements by digital analysis when compared with an "ideally clean" slab, showed an $18.12 \%$ media cleaning percentage, which is slightly lower than the salt removal. This agrees with previous results that showed that there is no direct relationship between salt reduction and visual cleaning [8]. It is important to indicate that high variability (high standard deviation) was observed on the treated slabs for all of the conducted analyzes. This agrees with other authors who indicated that building material desalination typically results in non-proportional, non-linear, and non-homogeneous salt removal [37,38]. Other authors indicated that controlling desalination is a very difficult task that can achieve results that are "contradictory and sometimes even undesirable on large monuments" [39]. 
In order to evaluate the long-term effects of the bio-desalination treatment, the same slabs were analyzed one year after the treatment. Ion conductivity results after one year showed very similar media values; this agrees with other authors who indicated that constant salt content was a sign that the desalination process had terminated [40]. But it is interesting that the analyzed slabs showed, one year after the bio-desalination treatment, an increase in nitrate reduction (up to $58 \%$ median values) and an increase in visual cleaning percentage (up to $37.78 \%$ median values). This visual cleaning and nitrate reduction increase over a one year period could be related to environmental conditions, slab salt mixture variations after the bio-desalination process, or even by long-term dry bio-desalination.

Salt behaviour is a very complex system, and multiple variables, such as salt type and quantity (supersaturation), substrate properties (e.g., porous size), and environment (temperature and humidity), are involved [36]. It is remarkable that the one year period coincided with the COVID-19 pandemic that resulted in the closing of the church and chapel for a few months and then reopened with an important restriction on the number of visitors. This could have influenced the chapel environment and, therefore, the surface salt content. Some authors have demonstrated that visitors' exhalations and corporal temperatures are able to modify salt crystallization patterns on artistic materials [41,42]. In addition, different field observations have shown how environmental variations in non-heated rooms are associated with salt crystallization behaviours $[43,44]$.

On the other hand, the bio-desalination process modifies the slab surfaces by removing an important percentage of nitrates and, therefore, modifies the previously existing salt mixtures. This slab superficial salt variation could have altered the salt behaviour in relation with the environment and produced the observed cleaning increase and nitrate reduction after one year. As described by other authors, in stone materials with salt mixtures, the particular salt combination composition is important to surface decay [45]. Some authors have demonstrated that changing stone surface parameters, such as surface tension using surfactants, directly affects salt crystallization [46]. Diverse species of the genus Pseudomonas have been reported to produce bio-surfactants, which might contribute to this long-term effect [47].

Another explanation of this phenomena could be related to remaining denitrifying bacteria that are active and produce a low-rate and long-term dry bio-desalination process. Recent publications have shown how other microorganisms (Saccharomyces cerevisiae) can be used to bioclean in situ stonework by using only environmental humidity and temperature [32].

Future research is needed to investigate the particular mechanisms that could be related to this observed increase in long-term nitrate-nitrite reduction, taking special consideration of the slab surface: microbiological analysis, thermohygrometric analysis, and salts analysis.

This work has contributed to the improvement and quantification of desalination evaluation by the use of non-destructive cleaning techniques based on digital imaging. Digital imaging is a non-destructive tool that is easy to use in situ and that allows for the process to be recorded and followed. Diverse efforts are shown in the field to use digital image analysis as a cheap non-destructive method for quantification of what experts can see by the naked eye [8,48-50]. In this work, a step forward has been achieved by standardizing a protocol that allows, by comparing with an "ideally cleaned" slab image, a relative percentage of cleaning to be obtained. Digital imaging is shown to be a useful method for verifying the effectiveness of biocleaning, which is complementary to the traditional salts and nitrates measurements. This digital image analysis could be used for other types of cleaning techniques and other types of cleaning areas in order to establish the degree of cleaning. 


\section{Conclusions}

This application oriented research has taken into account the practical aspects conservators face in their in situ daily work, such as materials choice, the practical needs of the high dimension $\mathrm{CH}$ building, selecting the most efficient, ease of use application and removal, and good cost/benefit ratios. This practical analysis has enabled, for the first time, the development and application of a bio-desalination protocol that is able to reduce the salt content of the high dimension granite pavement of Santa Maria del conxo Chapel. This innovative application protocol could be transferable to other large scale in situ biocleaning strategies. Furthermore, digital image analysis tools have been improved in order to convert the visual observations of cleaning into a quantitative cleaning percentage.

New frontiers of intervention are opening, and the obtained results contribute by giving conservators a new choice of a green desalination treatment procedure suitable for high dimension restoration sites.

Author Contributions: Conceptualization, P.B.-R. and L.P.-C.; Experimental procedures and methodology on bio-desalination P.B.-R. and Á.F.-S.; bio-desalination investigation, formal analysis, and data curation P.B.-R.; Digital image software design, validation, and analysis I.B.; writing_-original draft preparation and visualization P.B.-R., L.P.-C., Á.F.-S., and I.B.; writing-review and editing, P.B.-R.; supervision, project administration, P.B.-R. and L.P.-C.; funding acquisition, P.B.-R., L.P.-C., and I.B. All authors have read and agreed to the published version of the manuscript.

Funding: This research was funded by CONSORCIO DE LA CIUDAD DE SANTIAGO, which promotes intervention studies in this building.

Acknowledgments: The authors wish to thank the Instituto Universitario de Restauración del Patrimonio (IRP) and Instituto de tecnologías y Aplicaciones Multimedia for their support. Authors wish to give special thanks to Mari Cruz Rochina Peñalver from the Instituto de Biología Molecular y Celular de Plantas (IBMCP) from the Universitat Politècnica de Valencia for their technical support and for allowing us to use their high-performance centrifuge for this project.

Conflicts of Interest: The authors declare no conflict of interest.

\section{References}

1. Bosch-Roig, P.; Ranalli, G. Biocleaning of Cultural Heritage treasures. In Biodeterioration and Preservation of Cultural Heritage Treasures; Mitchel, R., Ed.; Archetype Publications: London, UK, 2018; pp. 169-183.

2. Bosch-Roig, P.; Ranalli, G. The safety of biocleaning technologies for Cultural Heritage. Front. Microbiol. 2014, 5, 155. [CrossRef]

3. Ranalli, G.; Zanardini, E. Biocleaning on Cultural Heritage: New frontiers of microbial biotechnologies. J. Appl. Microbiol. 2021, 1-21. [CrossRef]

4. Lombardi, E.; Balloi, A.; Troiano, F.; Gulotta, D.; Polo, A.; Gioventù, E.; Sorlini, C.; Cappitelli, F.; Daffonchio, D. Strategies for increasing the scale of biocleaning treatment through sulfate crust bioremoval. In Proceedings of the Built Heritage 2013 Monitoring Conservation Management, Milano, Italy, 18-20 November 2013; Politecnico di Milano: Milano, Italy, 2013; pp. 1424-1430.

5. Romano, I.; Abbate, M.; Poli, A.; D'Orazio, L. Bio-cleaning of nitrate salt efflorescence on stone samples using extremophilic bacteria. Sci. Rep. 2019, 9, 1-11. [CrossRef]

6. Soffritti, I.; D'Accolti, M.; Lanzoni, L.; Volta, A.; Bisi, M.; Mazzacane, S.; Caselli, E. The Potential Use of Microorganisms as Restorative Agents: An Update. Sustainability 2019, 11, 3853. [CrossRef]

7. Gioventù, E.; Lorenzi, P.F.; Villa, F.; Sorlini, C.; Rizzi, M.; Cagnini, A.; Griffo, A.; Cappitelli, F. Comparing the bioremoval of black crusts on colored artistic lithotypes of the Cathedral of Florence with chemical and laser treatment. Int. Biodeterior. Biodegrad. 2011, 65, 832-839. [CrossRef]

8. Bosch-Roig, P.; Allegue, H.; Bosch, I. Granite Pavement Nitrate Desalination: Traditional Methods vs. Biocleaning Methods. Sustainability 2019, 11, 4227. [CrossRef]

9. Cappitelli, F.; Zanardini, E.; Toniolo, L.; Abbruscato, P.; Ranalli, G.; Sorlini, C. Bioconservation of the marble base of the Pietà Rondanini by Michelangelo Buonarroti. Geophys. Res. Abstr. 2005, 7, 06675.

10. Polo, A.; Cappitelli, F.; Brusetti, L.; Principi, P.; Villa, F.; Giacomucci, L.; Ranalli, G.; Sorlini, C. Feasibility of Removing Surface Deposits on Stone Using Biological and Chemical Remediation Methods. Microb. Ecol. 2010, 60, 1-14. [CrossRef] [PubMed]

11. Troiano, F.; Gulotta, D.; Balloi, A.; Polo, A.; Toniolo, L.; Lombardi, E.; Daffonchio, D.; Sorlini, C.; Cappitelli, F. Successful combination of chemical and biological treatments for the cleaning of stone artworks. Int. Biodeterior. Biodegrad. 2013, 85, 294-304. [CrossRef]

12. Martino, M.; Schiavone, S.; Palla, F.; Pellegrino, L.; De Castro, E.; Balloi, A. Bioremoval of sulphate layer from a 15th century polycrome marble artifact. Conserv. Sci. Cult. Herit. 2015, 15, 235-243. 
13. Bosch-Roig, P.; Regidor-Ros, J.L.; Soriano-Sancho, P.; Doménec-Carbó, M.T.; Montes-Estelle s, R.M. Ensayos de biolimpieza con bacterias en pinturas murales. Arché 2010, 4-5, 115-122.

14. Lustrato, G.; Alfano, G.; Andreotti, A.; Colombini, M.P.; Ranalli, G. Fast biocleaning of mediaeval frescoes using viable bacterial cells. Int. Biodeterior. Biodegrad. 2012, 69, 51-61. [CrossRef]

15. Bosch-Roig, P.; Regidor-Ros, J.L.; Soriano-Sancho, P.; Montes-Estellés, R.M. Biocleaning of animal glue on wall paintings by Pseudomonas stutzeri. Chem. Today 2013, 31, 50-53.

16. Roig, P.B.; Ros, J.L.R.; Montes-Estelles, R.M. Biocleaning of nitrate alterations on wall paintings by Pseudomonas stutzeri. Int. Biodeterior. Biodegrad. 2013, 84, 266-274. [CrossRef]

17. Metaldi, S. Applicazione sperimentale di batteri solfato riduttori sul pigmento azzurrite. In Proceedings of the I batteri nel restauro, Thiene, Italy, 28 September 2013.

18. Mazzoni, M.; Alisi, C.; Tasso, F.; Cecchini, A.; Marconi, P.; Sprocati, A.R. Laponite micro-packs for the selective cleaning of multiple coherent deposits on wall paintings: The case study of Casina Farnese on the Palatine Hill (Rome-Italy). Int. Biodeterior. Biodegrad. 2014, 94, 1-11. [CrossRef]

19. Balloi, A.; Lombardi, E.; Troiano, F.; Polo, A.; Cappitelli, F.; Gulotta, D.; Toniolo, L.; Lucchini, A. Sulfate reducing bacteria as bio-cleaning agents: Development of new methodologies and study cases. Conserv. Sci. Cult. Herit. 2015, 15, 109-119.

20. Panella, E.; Giovannone, C.; Bartolini, M.; Fondi, V. Biotechnology in the conservation field: Removal of sulphates using bacteria and bioconsolidation of paintings and stuccos. Conserv. Sci. Cult. Herit. 2019, 19, 157-175.

21. Ranalli, G.; Zanardini, E.; Rampazzi, L.; Corti, C.; Andreotti, A.; Colombini, M.P.; Bosch-Roig, P.; Lustrato, G.; Giantomassi, C.; Zari, D.; et al. Onsite advanced biocleaning system for historical wall paintings using new agar-gauze bacteria gel. J. Appl. Microbiol. 2019, 126, 1785-1796. [CrossRef]

22. Alfano, G.; Lustrato, G.; Belli, C.; Zanardini, E.; Cappitelli, F.; Mello, E.; Sorlini, C.; Ranalli, G. The bioremoval of nitrate and sulfate alterations on artistic stonework: The case-study of Matera Cathedral after six years from the treatment. Int. Biodeterior. Biodegrad. 2011, 65, 1004-1011. [CrossRef]

23. Rampazzi, L.; Andreotti, A.; Bressan, M.; Colombini, M.P.; Corti, C.; Cuzman, O.; D’Alessandro, N.; Liberatore, L.; Palombi, L.; Raimondi, V.; et al. An interdisciplinary approach to a knowledge-based restoration: The dark alteration on Matera Cathedral (Italy). Appl. Surf. Sci. 2018, 458, 529-539. [CrossRef]

24. Ranalli, G.; Alfano, G.; Belli, C.; Lustrato, G.; Colombini, M.P.; Bonaduce, I.; Zanardini, E.; Abbruscato, P.; Cappitelli, F.; Sorlini, C. Biotechnology applied to cultural heritage: Borestoration of frescoes using viable bacterial cells and enzymes. J. Appl. Microbiol. 2005, 98, 73-83. [CrossRef] [PubMed]

25. García Morales, S.; Otero Ortiz de Cosca, R.; Allegue Castelos, H. Investigación Sobre El Oscurecimiento Húmedo Que Afecta Al Enlosado De La Capilla Del Cristo De Santa María De Conxo; Cuadernos técnicos; Consorcio de Santiago Oficina Técnica: Santiago de Compostela, Spain, 2016. Available online: https://issuu.com/consorciodesantiago/docs/conxo_oscurecimiento_humedo (accessed on 16 April 2021).

26. Ranalli, G.; Chiavarini, M.; Guidetti, V.; Marsala, F.; Matteini, M.; Zanardini, E.; Sorlini, C. The use of microorganisms for the removal of nitrates and organic substances on artistic stoneworks. In Proceedings of the 8th International Congress on Deterioration and Conservation of Stone, Berlin, Germany, 30 September-4 October 1996.

27. May, E.; Webster, A.M.; Inkpen, R.; Zamarreno, D.; Kuever, J.; Rudolph, C.; Warcheid, T.; Sorlini, C.; Cappitelli, F.; Zanardini, E.; et al. The BIOBRUSH Project for bioremediation of heritage stone. In Heritage Microbiology and Science. Microbes, Monuments and Maritime Materials; May, E., Jones, M., Mitchell, J., Eds.; RCS Publishing: Cambridge, UK, 2008; pp. 76-93.

28. Vidakovic, A.; Sovljanski, O.; Vucurovic, D.; Racic, G.; Djilas, M.; Curcic, N.; Markov, S. Novel denitrifying bacteria Pseudomonas stutzeri strain D1-From isolation to the biomass production. Chem. Ind. Chem. Eng. Q. 2019, 25, 403-415. [CrossRef]

29. Noble, R.C.; Overman, S.B. Pseudomonas stutzeri infection a review of hospital isolates and a review of the literature. Diagn. Microbiol. Infect. Dis. 1994, 19, 51-56. [CrossRef]

30. Atlas, R.M.; Chowdhury, A.N.; Gauri, K.L. Microbial calcification of gypsum-rock and sulfated marble. J. Stud. Conserv. 1988, 33, 149-153.

31. Bosch-Roig, P.; Lustrato, G.; Zanardini, E.; Ranalli, G. Biocleaning of Cultural Heritage stone surfaces and frescoes: Which delivery system can be the most appropriate? Ann. Microbiol. 2014, 65, 1227-1241. [CrossRef]

32. Ranalli, G.; Bosch-Roig, P.; Crudele, S.; Rampazzi, L.; Corti, C.; Zanardini, E. Dry biocleaning of artwork: An innovative methodology for Cultural Heritage recovery? Microb. Cell 2021, 8, 91-105. [CrossRef]

33. Yang, J.; Feng, L.; Pi, S.; Cui, D.; Ma, F.; Zhao, H.-P.; Li, A. A critical review of aerobic denitrification: Insights into the intracellular electron transfer. Sci. Total. Environ. 2020, 731, 139080. [CrossRef] [PubMed]

34. Franco, B.; Gisbert, J.; Mateos, I.; Navarro, P. Deterioro de los materiales pétreos por sales: Cinética del proceso, cartografía y métodos de extracción. In Proceedings of the I Congreso GEIIC, Valencia, Spain, 25-27 November 2002; pp. 287-294. Available online: https:/ / www.ge-iic.com/wp-content/uploads/2006/06/Franco_Belen.pdf (accessed on 20 May 2021).

35. Randazzo, L.; Montana, G.; Castiglia, A.; La Russa, M.F. Salt extraction from lime-based mortars: An experimental study using different poultice formulations. Constr. Build. Mater. 2020, 255, 119391. [CrossRef]

36. Doehne, E. Salt weathering: A selective review. Geol. Soc. Lond. Spéc. Publ. 2002, 205, 51-64. [CrossRef] 
37. Bromblet, P.; Verges-Belmin, V. The removal of sulfates from calcareous stone outdoor statuary: A questionable practice. In Proceedings of the Le dessalement des matériaux Poreux. 7es journées d'études de la SFIIC, Poitiers, France, 9-10 May 1996; pp. 55-63.

38. Charola, A.E. Salts in the deterioration of porous materials: An overview. J. Am. Inst. Conserv. 2000, 39, 327-343. [CrossRef]

39. Siedel, H. Experiences from desalting of tuffstone and sandstone monuments by compresses. In Proceedings of the Le dessalement des matériaux poreux. 7es journées d'études de la SFIIC, Poitiers, France, 9-10 May 1996; pp. 191-198.

40. Zornoza-Indart, A. Técnicas de desalación. In La Conservación de los Geomateriales utilizados en el Patrimonio; Programa Geomateriales: Madrid, Spain, 2012; pp. 143-154.

41. Wust, R.; McLane, J. Rock deterioration in the Royal Tomb of Seti I, Valley of the Kings, Luxor, Egypt. Eng. Geol. 2000, 58, 163-190. [CrossRef]

42. Wüst, R.A.; Schlüchter, C. The Origin of Soluble Salts in Rocks of the Thebes Mountains, Egypt: The Damage Potential to Ancient Egyptian Wall Art. J. Archaeolog. Sci. 2000, 27, 1161-1172. [CrossRef]

43. Arnold, A.; Zehnder, K. Decay of stony materials by salts in humid atmosphere. In Proceedings of the 6th International Congress on Deterioration and Conservation of Stone, Torun, Poland, 12-14 September 1988; Ciabach, J., Ed.; Copernicus University Press: Torun, Poland, 1988; pp. 138-148.

44. Cantón, Y.; Solé-Benet, A.; Queralt, I.; Pini, R. Weathering of a gypsum-calcareous mudstone under semi-arid environment at Tabernas, SE Spain: Laboratory and field-based experimental approaches. Catena 2001, 44, 111-132. [CrossRef]

45. Williams, R.B.G.; Robinson, D.A. Experimental frost weathering of sandstone by various combinations of salts. Earth Surf. Process. Landf. 2001, 26, 811-818. [CrossRef]

46. Rodriguez-Navarro, C.; Doehne, E.; Sebastian, E. Influencing Crystallization Damage in Porous Materials through the Use of Surfactants: Experimental Results Using Sodium Dodecyl Sulfate and Cetyldimethylbenzylammonium Chloride. Langmuir 2000, 16, 947-954. [CrossRef]

47. Mukherjee, A.K.; Das, K. Microbial Surfactants and Their Potential Applications: An Overview. In Advances in Experimental Medicine and Biology; Springer: New York, NY, USA, 2010; Volume 672.

48. Gazzano, C.; Favero-longo, S.E.; Matteucci, E.; Piervittori, R. Image analysis for measuring lichen colonization and within stonework. Lichenologist 2009, 41, 299-313. [CrossRef]

49. Miller, A.Z.; Rogerio-Candelera, M.A.; Dionísio, A.; Macedo, M.F.; Saiz-Jimenez, C. Microalgae, as biodeteriogens of stone cultural heritage: Qualitative and quantitative research by non-contact techniques. In Microalgae: Biotechnology, Microbiology and Energy; Johanssen, M.N., Ed.; Nova Science Publishers: New York, NY, USA, 2011; pp. 345-358.

50. Coutinho, M.L.D.; Miller, A.Z.; Gutierrez-Patricio, S.; Hernandez-Marine, M.; Gómez-Bolea, A.; Rogerio-Candelera, M.A.; Philips, A.; Jurado, V.; Saiz-Jimenez, C.; Macedo, M.F. Microbial communities on deteriorated artistic tiles from Pena National Palace (Sintra, Portugal). Int. Biodeterior. Biodegrad. 2013, 84, 322-332. [CrossRef] 